\title{
Fermentation of tartrate enantiomers by anaerobic bacteria, and description of two new species of strict anaerobes, Ruminococcus pasteurii and Ilyobacter tartaricus*
}

\author{
Bernhard Schink \\ Fakultät für Biologie, Universität Konstanz, Postfach 5560, D-7750 Konstanz, Federal Republic of Germany
}

\begin{abstract}
Enumerations of tartrate-fermenting anaerobic bacteria with $\mathrm{L}-$, D-, and m-tartrate as substrates revealed that $\mathrm{L}$-tartrate fermenters outnumbered $\mathrm{D}$ - and $\mathrm{m}$-tartrate fermenters by one to three orders of magnitude in all three anoxic environments studied.

Highest numbers of tartrate-fermenting bacteria were found in freshwater creek sediments, less in polluted marine channels, and lowest numbers in anoxic sewage digestor sludge. Prevailing bacteria were isolated on every tartrate enantiomer. They all degraded tartrates via oxaloacetate.

D- and m-tartrate-fermenting anaerobes were able to ferment L-tartrate as well, and were assigned to the genera Bacteroides, Acetivibrio, and Ilyobacter. L-Tartrate-fermenting anaerobes only utilized this enantiomer, and were characterized in more detail. Fermentation products on tartrate, citrate, pyruvate, and oxaloacetate were acetate, formate, and carbon dioxide. On fructose and glucose, also ethanol was formed. Freshwater isolates were Gram-positive cocci with large slime capsules, and were described as a new species, Ruminococcus pasteurii. Saltwater isolates were Gram-negative short rods, and were also described as a new species, Ilyobacter tartaricus. The guanosine-plus-cytosine content of the DNA was $45.2 \%$ and $33.1 \%$, respectively.
\end{abstract}

Key words: Tartrate enantiomers - Ruminococcus pasteurii - Ilyobacter tartaricus - Tartrate dehydratase Stereospecificity - Anaerobic degradation

$\mathrm{L}-(+)$-Tartaric acid is widely distributed in nature and occurs in many fruits, free and combined with potassium, calcium, or magnesium (Windholz et al. 1976). It is a byproduct of wine fermentation and is used for industrial purposes. In contrary, the other tartrate isomers only occur very rarely in nature.

Already in 1858, Pasteur observed selective anaerobic degradation of L-tartrate in a racemic mixture of $D$ - and L-ammonium-tartrate. On this observation, he based his theory of biological handedness (Pasteur 1858). Later, other authors reported anaerobic L-tartrate degradation by Aerobacter aerogenes (Barker 1936), Clostridium sp. (Tabachnick and Vaughn 1948; Mercer and Vaughn 1951), Bacillus (Krampitz and Lynen 1956) and "Pseudomonas" strains (Nomura and Sakaguchi 1955; LaRivière 1956) as well as Veillonella alcalescens (De Vries et al. 1977). Fer-

\footnotetext{
* Dedicated to Prof. Dr. H. G. Schlegel on occasion of his 60 . birthday
}

mentation products were acetate, ethanol, lactate, propionate, succinate, carbon dioxide and hydrogen. Phototrophic utilization of L-tartrate was reported for Rhodopseudomonas sphaeroides (van Niel 1944). Aerobically, L-tartrate is decomposed by coliform bacteria (Vaughn et al. 1946) and Pseudomonas species (Shilo 1957; Dagley and Trudgill 1963). Some Salmonella species and some

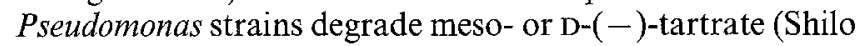
and Stanier 1957; Rode and Giffhorn 1982). Degradation usually proceeds via dehydratation to oxaloacetate (Barker 1936; Nomura and Sakaguchi 1955; Hurlbert and Jakoby 1965); alternative pathways are decarboxylation to glycerate as with a Pseudomonas strain (Dagley and Trudgill 1963) or oxidation to oxaloglycolate as found in mitochondria (Kun 1956). The present investigation was initiated in order to compare the potential of anaerobic microbial degradation of the different tartrate isomers in natural and man-made anoxic ecosystems.

\section{Materials and methods}

The following strains were isolated in pure culture from enrichment cultures inoculated with mud samples:

Strains KoTa1, KoTa2 from anoxic digestor sludge of the municipal sewage plant at Konstanz, FRG.

Strains WoTa1, WomTa1, ASDTa1 from black anoxic mud of polluted freshwater creeks near Konstanz, FRG.

Strains GraTa1, GraTa2 and CumTa1 from anoxic marine sediment of Canal Grande and Rio Marin in Venice, Italy, as well as marine sediment sampled at Cuxhaven, FRG.

Methanospirillum hungatei strain M1 h was isolated from digested sludge of the sewage plant at Göttingen, FRG.

\section{Cultivation and analyses}

All procedures for cultivation and isolation as well as all methods for analysis of metabolic products were as described in earlier papers (Widdel and Pfennig 1981; Schink and Pfennig 1982). For isolation of pure cultures, the agar shake culture method (Pfennig 1978) was applied. Formate was quantified by a colorimetric method (Lang and Lang 1972). Protein was determined after Hartree (1972). Tartrate dehydratase was assayed in crude cell extracts obtained by French pressure cell treatment according to Bergmeyer (1974). All chemicals were of reagent grade quality and obtained from Merck, Darmstadt; Serva, Heidelberg; Fluka, Neu-Ulm, and Sigma, München, FRG. 
Table 1. Enumeration of tartrate-degrading anaerobes in three different anoxic environments (cells/ml)

\begin{tabular}{|c|c|c|c|}
\hline \multirow[t]{2}{*}{ Environments } & \multicolumn{3}{|l|}{ Substrates } \\
\hline & L-Tartrate & D-Tartrate & m-Tartrate \\
\hline Anoxic sewage sludge (Konstanz) & 93 & 4 & $<1$ \\
\hline Anoxic freshwater creek sediments (near Konstanz) & $1.5-11 \times 10^{4}$ & $1.5 \times 10^{3}$ & 460 \\
\hline Anoxic marine sediment (Rio Marin, Venice) & $2.4-4.6 \times 10^{3}$ & 43 & 240 \\
\hline
\end{tabular}

Table 2. Substrates utilized by tartrate-degrading isolates

\begin{tabular}{|c|c|c|c|c|c|c|}
\hline \multirow[t]{2}{*}{ Substrate } & \multicolumn{6}{|l|}{ Strains } \\
\hline & $\begin{array}{l}\text { Concentration } \\
(\mathrm{mM})\end{array}$ & ASDTa1 & WomTa1 & CumTa1 & KoTa2 & GraTa2 \\
\hline L-Tartrate & 10 & + & + & + & + & + \\
\hline D-Tartrate & 10 & + & \pm & - & - & - \\
\hline m-Tartrate & 10 & - & \pm & + & - & - \\
\hline Citrate & 10 & + & + & + & + & + \\
\hline Pyruvate & 10 & - & + & + & + & + \\
\hline Oxaloacetate & 10 & - & + & + & + & + \\
\hline Malate & 10 & \pm & - & - & - & - \\
\hline Fumarate & 10 & \pm & - & - & - & - \\
\hline Glycerate & 10 & $\overline{+}$ & - & - & - & - \\
\hline Glycerol & 10 & - & - & - & - & + \\
\hline Glucose & 2 & + & - & + & + & + \\
\hline Fructose & 2 & + & - & + & + & + \\
\hline Xylose & 5 & \pm & - & - & + & - \\
\hline Arabinose & 5 & \pm & - & - & + & - \\
\hline
\end{tabular}

$(+)$ Good growth; $(-)$ no growth; $( \pm)$ weak growth

Table 3. Dehydratase activities for tartrate enantiomers in crude cell extracts of isolated strains (mkat per $\mathrm{kg}$ protein)

\begin{tabular}{lccccc}
\hline $\begin{array}{l}\text { Tartrate } \\
\text { enantiomer }\end{array}$ & \multicolumn{5}{l}{ Strains } \\
\cline { 2 - 6 } & ASDTa1 & WomTa1 & CumTa1 & KoTa2 & GraTa2 \\
\hline L-Tartrate & 2.17 & 0.85 & 0.71 & 19.1 & 8.0 \\
D-Tartrate & 11.18 & 0.38 & $<0.1$ & $<0.1$ & $<0.1$ \\
m-Tartrate & $<0.1$ & 5.17 & 4.0 & $<0.1$ & $<0.1$ \\
\hline
\end{tabular}

Strains were grown in 11 cultures with $20 \mathrm{mmol} / 1$ of the respective tartrate enantiomer used for their isolation. Cell extracts used for enzyme assays contained $5.1-17.8 \mathrm{mg}$ protein per $\mathrm{ml}$

\section{Results}

\section{Enumeration and isolation experiments}

Enumerations of anaerobic tartrate-fermenting bacteria were carried out in mineral medium with $10 \mathrm{mM}$ L-, D-, and $\mathrm{m}$-tartrate as substrate using the three tube most-probablenumber technique. After 4 weeks of incubation, tubes were checked for growth and product formation, and numbers of tartrate-fermenting anaerobes were calculated from positive tubes according to standard tables (American Public Health Association 1969). Acetate and methane were the only fermentation products detected. Numbers of L-tartratefermenting anaerobes were highest in freshwater creek sedi- ments, smaller in marine sediments of a channel in Venice, and very small in anoxic sewage sludge (Table 1 ). In every single sample examined, numbers of $\mathrm{D}$ - and $\mathrm{m}$-tartratedegrading anaerobes were lower than those of L-tartratedegrading anaerobes. Subcultures were inoculated from final dilution tubes on every enantiomer, and were purified in agar shake dilution series after two further transfers. The isolates were characterized with respect to specificity for their isolation substrate, to physiology, and cell morphology.

\section{General characterization of isolated strains}

The substrates utilized for growth by tartrate-degrading isolates are listed in Table 2. The strains isolated with L-tartrate did not utilize any other tartrate enantiomer whereas those strains isolated with $\mathrm{D}$ - or $\mathrm{m}$-tartrate were also able to grow on L-tartrate; one freshwater isolate grew on all three tartrates. All strains exhibited tartrate dehydratase activities for their respective isolation enantiomer in the range of $0.4-19.1$ mkat per $\mathrm{kg}$ protein (Table 3). Strains ASDTa1, WomTa1, and CumTa1 also showed weak dehydratase activities for the other tartrate enantiomers used for growth. Strain ASDTa1 was isolated as prevalent $\mathrm{D}$-tartrate-degrading anaerobe from freshwater creek sediments. Cells were Gram-negative straight to slightly curved slender rods motile by probably polar flagella. Fermentation products were acetate, propionate and formate. The organism behaved aerotolerant in agar shake gradient cultures, and reduced nitrate to nitrite. Sulfur 

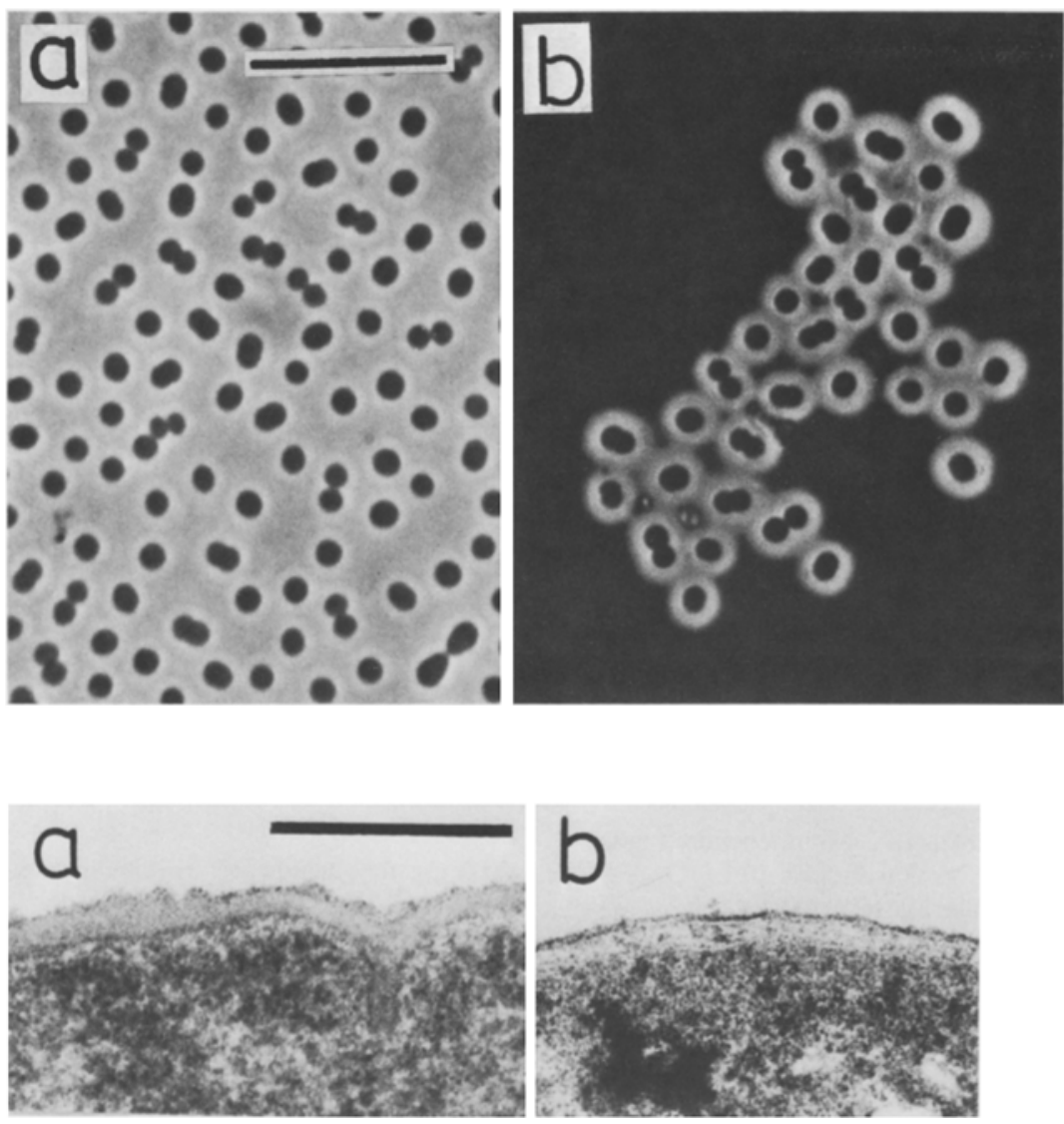

Fig. 1

Phase contrast photomicrograph of strain KoTa2. a Fresh culture grown on L-tartrate;

b Indian ink preparation. Bar equals $10 \mu \mathrm{m}$ for both prints

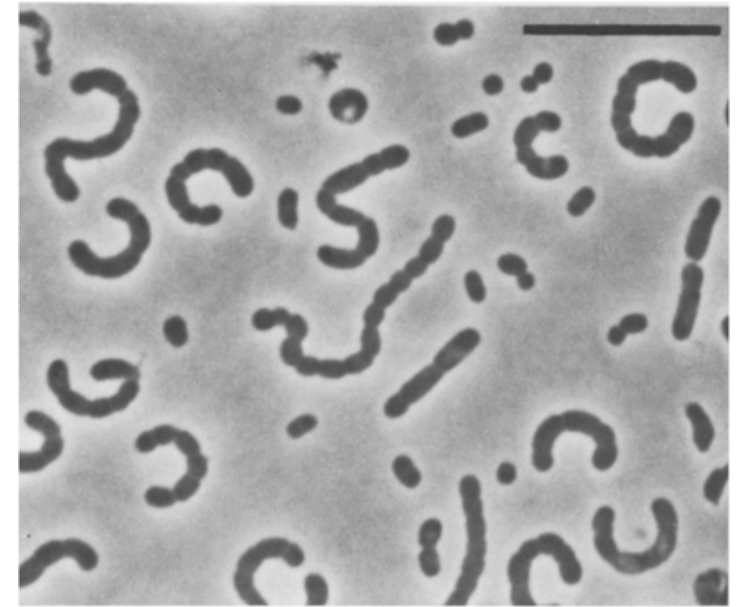

Fig. 3. Phase contrast photomicrographs of marine isolate strain GraTa2. Bar equals $10 \mu \mathrm{m}$ for both prints

compounds were not reduced. It was assigned to the genus Bacteroides.

Strain WomTa1 was the prevalent $\mathrm{m}$-tartrate-fermenting anaerobe in freshwater creeks. Cells were Gram-negative small, very motile vibrioid rods. Acetate and formate were the only detectable fermentation products. No growth was found on sugars. Metabolism was strictly anaerobic; nitrate or oxidized sulfur compounds were not reduced. This strain was assigned to the genus Acetivibrio.
Strain CumTa1 was isolated as prevalent $\mathrm{m}$-tartratedegrading anaerobe from marine sediments. Cells were Gram-negative straight rods. Acetate and formate were the only fermentation products; on glucose and fructose, also ethanol was formed. Neither nitrate nor sulfur compounds were reduced. This strain was classified with the genus Ilyobacter (Stieb and Schink 1984).

\section{Characterization of strain KoTa2}

Of three similar L-tartrate-fermenting isolates from freshwater creek sediments and sewage sludge, strain KoTa2 was chosen for further characterization. Cells were cocci, 1.0$1.5 \mu \mathrm{m}$ in diameter, either single or in pairs (Fig. $1 \mathrm{a}$ ). Indian ink preparations made large slime capsules visible (Fig. 1b). Cells were nonmotile and stained weakly Gram-positive. In ultrathin sections, a typical Gram-positive cell wall architecture was visible, and the mode of cell fission was also typical of Gram-positive cells (Fig. 2a). Spore formation was not observed. The guanine-plus-cytosine content of the DNA was $45.2 \pm 1.0 \%$.

Strain KoTa2 grew fast with a minimum doubling time of $1.2 \mathrm{~h}\left(\mu_{\max }=0.578 \mathrm{~h}^{-1}\right)$ at $35^{\circ} \mathrm{C}$. Growth was possible also at low temperatures: Cells grew at $4^{\circ} \mathrm{C}$ with $24 \mathrm{~h}$ and at $0^{\circ} \mathrm{C}$ with $32 \mathrm{~h}$ doubling time (in the presence of $2 \%$ ethylene glycol), and no growth was found at $-2^{\circ} \mathrm{C}$ and $45^{\circ} \mathrm{C}$. The $\mathrm{pH}$ limits of growth were $\mathrm{pH} 5.5$ and 8.8 with an optimum between 7.0 and 8.0. For optimal growth in mineral medium, biotin was the only vitamin required. $\mathrm{NaCl}$ inhibited growth at concentrations higher than $1 \%$. 
Table 4. Stoichiometry of fermentation and growth yields of isolates obtained on L-tartrate

\begin{tabular}{|c|c|c|c|c|c|c|c|c|}
\hline \multirow[t]{2}{*}{ Substrate } & \multirow{2}{*}{$\begin{array}{l}\text { Amount of } \\
\text { substrate } \\
\text { degraded } \\
(\mu \mathrm{mol})\end{array}$} & \multirow{2}{*}{$\begin{array}{l}\text { Cell dry } \\
\text { weight } \\
\text { formed } \\
(\mathrm{mg})^{\mathrm{a}}\end{array}$} & \multirow{2}{*}{$\begin{array}{l}\text { Substrate } \\
\text { assimi- } \\
\text { lated } \\
(\mu \mathrm{mol})^{b}\end{array}$} & \multicolumn{3}{|c|}{ Products formed $(\mu \mathrm{mol})$} & \multirow{2}{*}{$\begin{array}{l}\text { Growth } \\
\text { yield } \\
\mathrm{mg} / \mathrm{mmol} \\
\text { substrate } \\
\text { utilized }\end{array}$} & \multirow{2}{*}{$\begin{array}{l}\text { Carbon } \\
\text { recovery } \\
\%\end{array}$} \\
\hline & & & & Acetate & Formate & Ethanol & & \\
\hline \multicolumn{9}{|l|}{ Strain KoTa2 } \\
\hline L-Tartrate & 200 & 2.1 & 34.6 & 171 & 195 & - & 10.6 & 100.1 \\
\hline Oxaloacetate & 200 & 1.01 & 16.6 & 176 & 214 & - & 5.06 & 101.6 \\
\hline Pyruvate & 200 & 1.11 & 18.3 & 170 & 206 & - & 5.6 & 98.6 \\
\hline Citrate & 200 & 2.02 & 22.2 & 370 & 192 & - & 10.1 & 97.4 \\
\hline Glucose & 40 & 1.11 & 6.3 & 44 & 72 & 26 & 27.8 & 104.8 \\
\hline Fructose & 40 & 1.26 & 7.0 & 38 & 72 & 25 & 31.6 & 100.0 \\
\hline \multicolumn{9}{|l|}{ Strain GraTa2 } \\
\hline L-Tartrate & 200 & 2.07 & 34.1 & 174 & 190 & - & 10.4 & 101.3 \\
\hline Oxaloacetate & 200 & 1.06 & 17.5 & 185 & 148 & - & 5.3 & 92.3 \\
\hline Pyruvate & 200 & 1.16 & 19.1 & 186 & 172 & - & 5.8 & 97.0 \\
\hline Citrate & 200 & 2.1 & 23.1 & 363 & 178 & - & 10.6 & 95.5 \\
\hline Glucose & 40 & 1.31 & 7.3 & 37 & 71 & 27 & 32.7 & 101.4 \\
\hline Fructose & 40 & 1.34 & 7.4 & 41 & 75 & 21 & 33.5 & 101.7 \\
\hline
\end{tabular}

Experiments were carried out in $20 \mathrm{ml}$ tubes. All figures are means of $2-6$ independent assays

a Cell dry weights were calculated by cell density using conversion factors $\left(0.1 \mathrm{OD}_{650} \hat{=} 23.6-25.3 \mathrm{mg}\right.$ dry weight per 1$)$ which were obtained by direct determination in $500 \mathrm{ml}$ cultures for each strain separate

b Substrate assimilated was calculated using the formula $\left(\mathrm{C}_{4} \mathrm{H}_{7} \mathrm{O}_{3}\right)$ for cell material

\section{Characterization of strain GraTa2}

Of three similar L-tartrate-fermenting isolates from marine sediments, strain GraTa2 was further characterized. Cells were short rods, $1.0 \times 1.2-2.5 \mu \mathrm{m}$ in size, often forming irregular, odd-shaped chains (Fig. 3). Slime capsules were small (not shown). Cells were nonmotile and stained Gramnegative. Ultrathin sections revealed a typical Gram-negative cell wall architecture (Fig. 2b). Spore formation was never observed. The guanine-plus-cytosine content of the DNA was $33.1 \pm 1.0 \%$. Strain GraTa2 grew optimally at $28^{\circ} \mathrm{C}$ with a minimum doubling time of $1.6 \mathrm{~h}$ $\left(\mu=0.433 \mathrm{~h}^{-1}\right)$; the temperature limits were 12 and $40^{\circ} \mathrm{C}$. The $\mathrm{pH}$ limits were $\mathrm{pH} 5.5$ and 8.0 ; the optimum was between pH 6.5 and 7.2. Growth was possible in mineral medium with at least $1 \% \mathrm{NaCl}$; no growth occurred in freshwater medium. No vitamins were required for growth on tartrate or glucose.

\section{Physiology of strains KoTa2 and GraTa2}

Strains KoTa2 and GraTa2 were very similar with respect to physiological properties. Besides L-tartrate, they both degraded citrate, pyruvate, oxaloacetate, glucose, and fructose. Strain KoTa2 grew on several other carbohydrates (listed at the end of the "Discussion" section), whereas strain GraTa1 grew on glycerol in the presence of acetate. Yeast extract was not used as a growth substrate, however, enhanced growth yields by $15-20 \%$.

Fermentation products of both strains on tartrate, citrate, pyruvate and oxaloacetate were formate, acetate and probably carbon dioxide, according to the following fermentation equations (Table 4):

Tartrate:

$\mathrm{C}_{4} \mathrm{H}_{4} \mathrm{O}_{6}{ }^{2-}+\mathrm{H}_{2} \mathrm{O} \rightarrow \mathrm{CH}_{3} \mathrm{COO}^{-}+\mathrm{HCOO}^{-}+\mathrm{HCO}_{3}^{-}+\mathrm{H}^{+}$
Citrate:

$\mathrm{C}_{6} \mathrm{H}_{5} \mathrm{O}_{7}{ }^{3-}+2 \mathrm{H}_{2} \mathrm{O} \rightarrow 2 \mathrm{CH}_{3} \mathrm{COO}^{-}+\mathrm{HCOO}^{-}+\mathrm{HCO}_{3}^{-}+\mathrm{H}^{+}$

Oxaloacetate:

$\mathrm{C}_{4} \mathrm{H}_{2} \mathrm{O}_{5}{ }^{2-}+2 \mathrm{H}_{2} \mathrm{O} \rightarrow \mathrm{CH}_{3} \mathrm{COO}^{-}+\mathrm{HCOOO}^{-}+\mathrm{HCO}_{3}^{-}+\mathrm{H}^{+}$

Pyruvate:

$\mathrm{C}_{3} \mathrm{H}_{3} \mathrm{O}_{3}^{-}+\mathrm{H}_{2} \mathrm{O} \rightarrow \mathrm{CH}_{3} \mathrm{COO}^{-}+\mathrm{HCOO}^{-}+\mathrm{H}^{+}$.

Fructose and glucose were degraded to acetate, ethanol, and formate according to the equation:

$\mathrm{C}_{6} \mathrm{H}_{12} \mathrm{O}_{6}+\mathrm{H}_{2} \mathrm{O} \rightarrow \mathrm{CH}_{3} \mathrm{COO}^{-}+\mathrm{CH}_{3} \mathrm{CH}_{2} \mathrm{OH}+2 \mathrm{HCOO}^{-}+3 \mathrm{H}^{+}$.

No cytochromes were detectable on cell-free extracts or membrane preparations of glucose- or tartrate-grown cells. In cocultures with the hydrogen- and formate-degrading methanogen Methanospirillum hungatei, acetate and methane were the only products of tartrate degradation, according ot the following equation:

$4 \mathrm{C}_{4} \mathrm{H}_{4} \mathrm{O}_{6}{ }^{2-}+5 \mathrm{H}_{2} \mathrm{O} \rightarrow 4 \mathrm{CH}_{3} \mathrm{COO}^{-}+7 \mathrm{HCO}_{3}^{-}+\mathrm{CH}_{4}+3 \mathrm{H}^{+}$.

\section{Discussion}

\section{Ecology and physiology of tartrate fermentation}

The present study demonstrates that all three tartrate isomers can be fermented anaerobically. Since L-tartrate is by far the most important enantiomer in nature, it is not astonishing that numbers of L-tartrate-fermenting anaerobes exceeded those of $\mathrm{D}$ - or m-tartrate-fermenters by one to three orders of magnitude. Highest numbers of 
tartrate-degrading anaerobes were found in freshwater creek sediments in which L-tartrate as a component of fresh plant matter probably plays a more important role as a substrate than in a highly polluted marine-channel or a sewage digestor. The fact that potassium tartrate is not degraded in wine is probably due to its low $\mathrm{pH}(\mathrm{pH} 3.2-3.7)$ and high ethanol content rather than to low temperature as the properties of our and earlier isolates suggest. Pasteur's early observation that only L-tartrate was fermented in a racemic mixture of both enantiomers was probably based on the fact that he used an inoculum enriched for several generations on L-tartrate. He described the bacteria involved as "little rods or granules of very small diameter, organized in clumps, and welded together by a sticky substance" (Pasteur 1858). To my knowledge, there is no slime-forming coccoid bacterium among the tartrate-fermenting anaerobes described so far. The organism described by Pasteur very well resembles strain KoTa2 presented in the present study.

All strains degraded tartrate via oxaloacetate, no matter if $\mathrm{L}-, \mathrm{D}-$, or m-tartrate was the substrate. The data at hand do not allow conclusions on whether the different tartrate dehydratase activities found in strains ASDTa1, WomTa1, and CumTa1 are due to different dehydratase enzyme proteins, or if they all are functions of one single enzyme protein with low substrate specificity, or if a racemase is involved. With one exception, all strains isolated converted tartrate to acetate, formate, and carbon dioxide. Degradation of tartrate and citrate via oxaloacetate and pyruvate would allow ATP synthesis only by acetate kinase. The cell yields obtained with all strains ranged around $10 \mathrm{~g}$ cell dry weight per mol of substrate, and thus agree with an energy yield of $1 \mathrm{~mol}$ ATP per mol of substrate degraded (Stouthamer 1979). With Veillonella alcalescens, a slightly higher cell yield was obtained on L-tartrate $(13.1 \mathrm{~g} / \mathrm{mol}$; De Vries et al. 1977), however, this bacterium can gain energy also during fumarate reduction to succinate, and was grown in the presence of yeast extract. On pyruvate and oxaloacetate, cell dry weights obtained only accounted for about half of those expected. The cell yields obtained during conversion of glucose and fructose to acetate, ethanol, and formate agree with an assumed formation of $3 \mathrm{~mol}$ ATP per mol of sugar degraded. Similar values were obtained with Ilyobacter polytropus which exhibits the same fermentation pattern on sugars (Stieb and Schink 1984).

\section{Taxonomy}

The $\mathrm{D}$ - and m-tartrate-fermenting isolates described in the present study were tentatively assigned to existing genera. The L-tartrate-fermenting strains were characterized in more detail. Although they both were very similar with respect to physiological properties, they appeared to be very different with respect ot cytological characters, e.g. Gram reaction, cell shape, guanine plus cytosine content of the DNA. Strain $\mathrm{KoTa} 2$ is a strictly anaerobic, Gram-positive coccus. Its fermentation pattern as well as the guanine plus cytosine content of the DNA do not allow affiliation with the genera Streptococcus, Leuconostoc, Pediococcus, Aerococcus, Peptococcus, or Sarcina (Buchanan and Gibbons 1974). The formation of acetate, formate, and ethanol from glucose is common in the genus Ruminococcus, and the guanine plus cytosine content of the DNA of reported strains (39.8$45.5 \%$ ) is close to that of strain KoTa2. Although strain KoTa2 lacks some typical properties of the genus
Ruminococcus, e.g. cellulose degradation or fastidious growth requirements, it appears justified to assign this strain to the genus Ruminococcus as a new species, $R$. pasteurii sp. nov.

Ruminococcus pasteurii sp. nov. pa. steu'ri.i.M.L. gen. attr. referring to Louis Pasteur who probably first enriched and observed this bacterium during studies on tartrate fermentation. Cocci, $1.0-1.5 \mu \mathrm{m}$ in diameter, single, in pairs or small packages, surrounded by thick slime capsules. Gram-positive, non-motile, non-sporeforming. Strictly anaerobic chemoorganotroph. L-Tartrate, citrate, oxaloacetate, pyruvate utilized for growth as well as a variety of sugars including glucose, fructose, lactose, sucrose, cellobiose, maltose, mannose, raffinose, sorbose, rhamnose, trehalose. No growth on D-tartrate, m-tartrate, glycerol, glycerate, formate, acetate, lactate, glyoxylate, glycolate, fumarate, malate, ethanol, ethylene glycol, 2,3-butanediol, 3-hydroxybutyrate, xylose, arabinose, cellulose, xylane, peptone, yeast extract. Fermentation products include acetate, formate, ethanol, and carbon dioxide. Growth in freshwater medium with less than $1 \%$ sodium chloride. Sulfate, sulfur, thiosulfate, sulfite, or nitrate not reduced. Indole not formed, gelatin or urea not hydrolyzed. No catalase activity, no cytochromes. Biotin required for growth in mineral medium.

Selective enrichment from freshwater sediments with L-tartrate as sole carbon and energy source.

$\mathrm{pH}$ range: $5.5-8.8$; optimum $\mathrm{pH} 7.0-7.5$. Temperature range: $0-42^{\circ} \mathrm{C}$; optimum temperature $35^{\circ} \mathrm{C}$.

DNA base ratio: $45.2 \pm 1.0 \% \mathrm{G}+\mathrm{C}$ (thermal denaturation). Habitats: anoxic muds in freshwater lakes and creeks. Type strain: KoTa2, DSM 2381, deposited in Deutsche Sammlung von Mikroorganismen, Göttingen.

The marine L-tartrate-fermenting isolate, strain GraTa2, is a Gram-negative, non-sporeforming strictly anaerobic rod which has to be assigned to the family Bacteroidaceae (Krieg and Holt 1984). Its simple growth requirements, fermentation pattern, cell shape, and guanine plus cytosine content of the DNA do not allow affiliation to any of the 12 so far accepted genera of this family. The isolate shares several important properties, especially the fermentation pattern on sugars, with the recently described Ilyobacter polytropus (Stieb and Schink 1984). Therefore, it is affiliated to this genus as a new species, Ilyobacter tartaricus sp. nov. Strain CumTa1 was affiliated with this species, too.

Ilyobacter tartaricus sp. nov. tar. ta'ri. cus.M.L.n. acidum tartaricum tartaric acid; tartaricus referring to tartaric acid as isolation substrate. Short, straight rods, $1.0 \times 1.2-1.2-$ $2.5 \mu \mathrm{m}$ in size, often in chains, surrounded by slime capsules, non-motile, Gram-negative, non-sporeforming.

Strictly anaerobic chemoorganotroph. Grows on L-tartrate, citrate, pyruvate, oxaloacetate, glucose, fructose, raffinose, glycerol. Fermentation products include acetate, formate, and ethanol. No growth on formate, acetate, lactate, methanol, ethanol, ethylene glycol, 2,3-butanediol, glycerate, malate, fumarate, glyoxylate, glycolate, mannose, maltose, lactose, sucrose, cellobiose, sorbose, rhamnose, trehalose, xylose, arabinose, peptone, yeast extract. Grows in saltwater medium with at least $1 \%$ sodium chloride. Oxidized sulfur compounds or nitrate not reduced.

Indole not formed, gelatin or urea not hydrolyzed. No catalase activity, no cytochromes. No vitamin requirements. Selective enrichment from marine sediments with L-tartrate as sole carbon and energy source. 
$\mathrm{pH}$ range: $5.5-8.0$; optimum $\mathrm{pH}$ 6.5-7.2. Temperature range: $10-40^{\circ} \mathrm{C}$; optimum temperature $28-34^{\circ} \mathrm{C}$. DNA base ratio: $33.1 \pm 1.0 \% \mathrm{G}+\mathrm{C}$ (thermal denaturation). Habitats: anoxic marine sediments. Type strain: GraTa2, DSM 2382, deposited in Deutsche Sammlung von Mikroorganismen, Göttingen.

Acknowledgements. The author is greatly indebted to Prof. Dr. Norbert Pfennig for support and valuable criticism. He also acknowledges gratefully the guidance and personal example bestowed upon him by his former teacher, Prof. Dr. H. G. Schlegel. Prof. Dr. F. Mayer helped with preparation and interpretation of electron micrographs. Technical help by Waltraud Dilling, Elisabeth Kayser, and Thomas Munsch is greatly appreciated. This work was in part supported by the Deutsche Forschungsgemeinschaft.

\section{References}

American Public Health Association Inc (ed) (1969) Standard methods for the examination of water and wastewater including bottom sediments and sludge. New York, pp 604-609

Barker HA (1936) On the fermentation of some dibasic $\mathrm{C}_{4}$-acids by Aerobacter aerogenes. Proc Acad Sci Amst 39:674

Bergmeyer HU (1974) Methoden der enzymatischen Analyse, 3rd edn. Verlag Chmie, Weinheim

Buchanan RE, Gibbons NE (1974) Bergey's manual of determinative bacteriology, 8 th edn. Williams and Wilkins Co, Baltimore

Dagley S. Trudgill PW (1963) The metabolism of tartaric acid by a Pseudomonas. A new pathway. Biochem J 89:22-31

De Vries W, Rietveld-Struijck TRM, Stouthamer AG (1977) ATP formation associated with fumarate and nitrate reduction in growing cultures of Veillonella alcalescens. Antonie van Leeuwenhoek 43:153-167

Hartree EF (1972) Determination of protein: a modification of the Lowry method that gives a linear photometric response. Anal Biochem 48:422-427

Hurlbert RE, Jakoby WB (1965) Tartaric acid metabolism. I. Subunits of $\mathbf{L}(+)$-tartaric acid dehydrase. J Biol Chem 240:27722777

Krampitz LO, Lynen F (1956) Formation of oxaloacetate from D-tartrate. Fed Proc 15:292-293

Krieg NR, Holt JG (1984) Bergey's manual of systematic bacteriology, 9th edn, vol 1. Williams and Wilkins, Baltimore London

Kun E (1956) Enzymatic mechanism of oxidation of tartrate. J Biol Chem 221:223-230

Lang E, Lang H (1972) Spezifische Farbreaktion zum direkten Nachweis der Ameisensäure. Z Analyt Chem 260:8-10
La Rivière HWM (1956) Intermediate products in tartrate decomposition by cell-free extracts of Pseudomonas putida under anaerobic conditions. Biochim Biophys Acta 21:190191

Mercer WA, Vaughn RH (1951) The characteristics of some thermophilic tartrate-fermenting anaerobes. J Bacteriol 62: $27-37$

Nomura M, Sakaguchi K (1955) The decomposition of L-(+)tartrate by microorganisms. J Gen Appl Microbiol 1:77-98

Pasteur L (1858) Mémoire sur la fermentation de l'acide tartrique. Compt Rend Acad Sci Paris 46:615-618

Pfennig N (1978) Rhodocyclus purpureus gen. nov. and sp. nov., a ring-shaped, vitamin $\mathrm{B}_{12}$-requiring member of the family Rhodospirillaceae. Int J Syst Bacteriol 28:283-288

Rode H, Giffhorn F (1982) Ferrous-or cobalt ion-dependent $\mathrm{D}-(-)$-tartrate dehydratase of pseudomonads: purification and properties. J Bacteriol 151:1602-1604

Schink B, Pfennig N (1982) Fermentation of trihydroxybenzenes by Pelobacter acidigallici gen. nov. sp. nov., a new strictly anaerobic, non-sporeforming bacterium. Arch Microbiol 133:195-201

Shilo $M$ (1957) The enzymic conversion of the tartaric acids to oxaloacetic acids. J Gen Microbiol 16:472-481

Shilo M, Stanier RY (1957) The utilization of the tartaric acids by pseudomonads. J Gen Microbiol 16:482-490

Stieb M, Schink B (1984) Ilyobacter polytropus gen. nov. sp. nov., a new non-sporing strict anaerobe exhibiting a very versatile fermentation metabolism. Arch Microbiol (submitted)

Stouthamer AH (1979) The search for correlation between theoretical and experimental growth yields. In: Quayle JR (ed) International review of biochemistry, microbial biochemistry, vol 21. University Park Press, Baltimore, pp 1-47

Tabachnick J, Vaughn RH (1948) Characteristics of tartratefermenting species of Clostridium. J Bacteriol 56:435-443

Van Niel CB (1944) The culture, general physiology, morphology, and classification of the nonsulfar purple and brown bacteria. Bacteriol Rev 8:1-118

Vaughn RH, Marsh GL, Stadtman TC, Cantino BC (1946) Decomposition of tartrates by the coliform bacteria. J Bacteriol 52:311-325

Widdel F, Pfennig N (1981) Studies on dissimilatory sulfate-reducing bacteria that decompose fatty acids. I. Isolation of new sulfate-reducing bacteria enriched with acetate from saline environments. Description of Desulfobacter postgatei gen. nov. sp. nov. Arch Microbiol 129:395-400

Windholz M, Budavari S, Stroumtsos LY, Fertig MN (1976) The Merck Index. Merck \& Co Inc, Rahway, New Jersey

Received March 2, 1984/Accepted April 13, 1984 